\title{
COL18A1 is highly expressed during human adipocyte differentiation and the SNP c.1136C $>T$ in its "frizzled" motif is associated with obesity in diabetes type 2 patients
}

\author{
FLAVIA I.V. ERRERA ${ }^{1,2}$, LUÍS H. CANANI ${ }^{3}$, ERIKA YEH ${ }^{1}$, ÉRIKA KAGUE ${ }^{1}$, \\ LUCIA M. ARMELIN-CORRÊA ${ }^{1}$, OSCAR T. SUZUKI ${ }^{1}$, BALDUÍNO TSCHIEDEL ${ }^{5}$, \\ MARIA ELIZABETH R. SILVA ${ }^{4}$, ANDRÉA L. SERTIÉ ${ }^{1}$ and MARIA RITA PASSOS-BUENO ${ }^{1}$ \\ ${ }^{1}$ Centro de Estudos do Genoma Humano, Departamento de Genética e Biologia Evolutiva, Instituto de Biociências, \\ Universidade de São Paulo, Rua do Matão 277, 05509-900 São Paulo, SP, Brasil \\ ${ }^{2}$ Faculdade de Medicina, Escola Superior de Ciências da Santa Casa de Vitória (EMESCAM), \\ Av. Nossa Senhora da Penha, 2190, 29045-102 Vitória, ES, Brasil \\ ${ }^{3}$ Departamento de Endocrinologia, Hospital de Clínicas de Porto Alegre, Universidade Federal do Rio Grande do Sul \\ Rua Ramiro Barcellos, 2350, 90035-903 Porto Alegre, RS, Brasil \\ ${ }^{4}$ Laboratório de Investigação Médica, LIM-18, Hospital das Clínicas da Universidade de São Paulo \\ Faculdade de Medicina, Av. Dr. Arnaldo, 455, 01246-903 São Paulo, SP, Brasil \\ ${ }^{5}$ Sessão de Endocrinologia, Hospital Conceição, Av. Francisco Trein, 596, 90013-901 Porto Alegre, RS, Brasil \\ Manuscript received on October 3, 2007; accepted for publication on January 21, 2008; \\ presented by ROGÉRIO MENEGHINI
}

\begin{abstract}
Collagen XVIII can generate two fragments, NC11-728 containing a frizzled motif which possibly acts in Wnt signaling and Endostatin, which is cleaved from the $\mathrm{NC1}$ and is a potent inhibitor of angiogenesis. Collagen XVIII and Wnt signaling have recently been associated with adipogenic differentiation and obesity in some animal models, but not in humans. In the present report, we have shown that COL18A1 expression increases during human adipogenic differentiation. We also tested if polymorphisms in the Frizzled (c.1136C > T; Thr379Met) and Endostatin (c.4349G > A; Asp1437Asn) regions contribute towards susceptibility to obesity in patients with type 2 diabetes (113 obese, BMI $\geq 30 ; 232$ non-obese, BMI $<30$ ) of European ancestry. No evidence of association was observed between the allele c. $4349 \mathrm{G}>\mathrm{A}$ and obesity, but we observed a significantly higher frequency of homozygotes c.1136TT in obese (19.5\%) than in non-obese individuals (10.9\%) $[\mathrm{P}=0.02 ; \mathrm{OR}=2.0$ (95\% CI: 1.07-3.73)], suggesting that the allele $\mathrm{c} .1136 \mathrm{~T}$ is associated to obesity in a recessive model. This genotype, after controlling for cholesterol, LDL cholesterol, and triglycerides, was independently associated with obesity $(\mathrm{P}=0.048)$, and increases the chance of obesity in 2.8 times. Therefore, our data suggest the involvement of collagen XVIII in human adipogenesis and susceptibility to obesity.
\end{abstract}

Key words: $C O L 18 \mathrm{Al}$, obesity, adipogenesis, endostatin, frizzled.

\section{INTRODUCTION}

COL18A1, located at chromosome 21q22.3, was first shown to have an important role in humans when we demonstrated that homozygous null mutations in this gene cause Knobloch syndrome (KS) (Sertié et al. 2000).

Correspondence to: Maria Rita Passos Bueno

E-mail: passos@ib.usp.br
$\mathrm{KS}$ is an autosomal recessive condition characterized by vitreo and retinal degeneration, macular abnormalities and occipital encephalocele (KS; OMIM 267750). The importance of collagen XVIII in retinal angiogenesis was further confirmed through the observation of ocular delayed hyaloid vessel regression in knockout col18a-/- mice (Fukai et al. 2002).

Collagen XVIII is an important proteoglycan of 
most basement membranes of the body which belongs to a distinct class of nonfibrillar collagens, called multiplexins. This protein forms homotrimers and contains a N-terminal non-collagenous domain (NC-11), 10 collagenous repeats alternated with 9 non-collagenous repeats and a C-terminal non-collagenous region, $\mathrm{NC}-1$ (Oh et al. 1994, Saarela et al. 1998). COL18A1 can be transcribed as 3 distinct isoforms by use of two promoters and an alternative splicing of the third exon. The three encoded collagen XVIII proteins differ only by their signal peptides and by part of the $\mathrm{N}$-terminal region of the NC11 domain, which contain respectively 303 (NC11303), 493 (NC11-493) and 728 (NC11-728) amino acid residues (Saarela et al. 1998, Elamaa et al. 2003). Collagen XVIII presents high expression levels in liver, kidney, retina and adipose tissue and the predominant isoform varies according to the tissue type (Saarela et al. 1998, Suzuki et al. 2002, Elamaa et al. 2003, NCBI UniGene Hs.517356).

At least two functional fragments can be released from collagen XVIII: Endostatin, a $20 \mathrm{kDa}$ fragment cleaved from the $\mathrm{NC1}$ region- common to the three collagen XVIII isoforms (ES-C18) (O'Reilly et al. 1997, John et al. 2005) and the N-terminal Frizzled cysteinerich domain cleaved from the NC11-728 variant (Frizzled-C18) (Elamaa et al. 2003). ES-C18 is a potent inhibitor of endothelial cell proliferation and migration with the ability to reduce tumor growth (O'Reilly et al. 1997, Sasaki et al. 1998). Collagen XVIII and ESC18 play several other functions, including apoptosis induction (Dhanabal et al. 1999, Schmidt et al. 2004) and maintenance of vascular permeability (Moulton et al. 2004). The Frizzled-C18 motif shows homology to secreted frizzled related proteins (sFRP). These proteins can block Wnt signaling either by interacting with Wnts to prevent them from binding to frizzled receptors or forming nonfunctional complexes with them (Wodarz and Nusse 1998). The function of the soluble FrizzledC18 motif is still unknown, but it is possibly involved in Wnt signaling as sFRPs does (Elaama et al. 2003, Quelard et al. 2006).

Although the molecular mechanisms regulated by collagen XVIII and its NC11 and NC1 functional fragments are still being investigated, it is unquestionable the functional role of collagen XVIII in angiogenesis. There- fore, variability in quantity or quality of collagen XVIII and its related fragments could be associated with the predisposition of human disorders dependent on angiogenesis (Passos-Bueno et al. 2006). Substantial evidence has established that growth of solid tumors is angiogenesis dependent whereas angiogenesis inhibition prevents it and can lead to regression of the lesions (Udagawa et al. 2002, Folkman 2002). Although we and others were not able to confirm the association between the SNP Asp 1437 Asn (D104N) at the endostatin region and prostate cancer (Iughetti et al. 2001, Macpherson et al. 2004, Passos-Bueno et al. 2006), several reports have shown that lower ES-C18 levels have been correlated with a worse tumor prognosis (Musso et al. 2001) and that the SNP D104N might be associated with breast cancer (Lourenço et al. 2006, Balasubramanian et al. 2007). Therefore, analysis of COL18A1 gene SNPs in diseases in which angiogenesis plays a role can provide further insights in the functional importance of this molecule in humans.

Adipose tissue is very unique as it can grow and regress throughout adulthood. Its growth, which can arise through increases in cell size (due to accumulation of triglycerides) and/or cell number (due to proliferation of preadipocytes and their subsequent differentiation into mature adipocytes), is largely angiogenesis dependent (Rupnick et al. 2002, Cao 2007, Nishimura et al. 2007). Collagen XVIII, which is abundant in adipose tissue (NCBI UniGene Hs.517356), is involved in angiogenesis control and it has been shown that its transcription levels increase during bovine adipocyte differentiation (Inoue-Murayama et al. 2000). However, the function of collagen XVIII in the molecular control of adipogenesis and obesity is very poorly characterized and it has not yet been investigated in humans. Therefore, in this study we have first evaluated if COL18A1 mRNA levels vary during in vitro adipogenesis of human adipose tissue-derived stem cells. In addition, we also aimed to verify if collagen XVIII would have any effect on the predisposition of obesity, as this is known to be a major risk factor for several diseases such as type 2 diabetes mellitus (DM2) and cardiovascular disorders. To achieve this goal, we tested if SNP c.1136C > T (Thr379Met), which is being here described for the first time, and SNP c.4349G > A (Asp1437Asn) are associated 
with obesity in a cohort of Brazilian patients with DM2. These SNPs are missense mutations in the coding region of the human COL181A and are located respectively in the NC11-728 (Frizzled-C18) and Endostatin (ES-C18) domains of the protein.

\section{MATERIALS AND METHODS}

In vitro ADIPOGENIC DIFFERENTIATION

Adipose tissue-derived mesenchymal stem cells were obtained from lipoaspirates of abdominal subcutaneous fat. The cells were isolated and cultured as described previously (Zuk et al. 2002, Costa et al. 2008, Bueno 2007). Their differentiation into adipocytes was induced by treatment of semi-confluent cells for 14 days with DMEM-HG supplemented with 10\% FBS (Hyclone), $1 \mu \mathrm{M}$ dexamethasone, $100 \mu \mathrm{M}$ indomethacin, $500 \mu \mathrm{M} 3-$ isobutyl-1-methylxanthine (IBMX), and $10 \mu \mathrm{g} / \mathrm{ml}$ insulin as standard protocol (Zuk et al. 2002). To assess neutral lipid content at day 14 after exposure to inducers of differentiation, mature adipocytes were washed with PBS, fixed with 4\% paraformaldehyde and stained with Oil Red O. A successful differentiation process was considered when it was observed that the majority of cells accumulated lipid vesicles in the cytoplasm. The use of human lipoaspirates to establish stem cell populations was accordingly to the guidelines of our local Ethical Committee.

\section{QUANTITATIVE REAL-TIME PCR (QRT-PCR)}

RNA extraction was conducted with trizol (Gibco) reagent at days 0 (no adipogenic induction medium), 3, 7 and 14 of the differentiation process. $5 \mu \mathrm{g}$ of total RNA was treated with 5 units of RQ1 RNase- Free DNAse (Promega). cDNAs were synthesized from $1 \mu \mathrm{g}$ of total RNA using SuperScript II (Invitrogen). Quantitative real time PCR was performed with SYBR Green PCR master mix in an ABI Prism 7100 system (Applied Biosystems) and approximately $50 \mathrm{ng}$ of cDNA was used to final reaction volume of $25 \mu \mathrm{L}$. The primers used in this study are listed in Table I; the COL18A1 primers amplify all isoforms. The PCR conditions were: $94^{\circ} \mathrm{C}$ for $15 \mathrm{sec}$ onds, $60^{\circ} \mathrm{C}$ for 30 seconds, and $72^{\circ} \mathrm{C}$ for 30 seconds for 45 cycles. The four samples acquired from adipogenic differentiation (time points $0,3,7$ and 14 days) were submitted to qRT-PCR and the threshold cycle (ct) for each individual PCR product was calculated by the instrument software. $\Delta \mathrm{Ct}$ was calculated with the difference between sample Cts of each time point of differentiation and reference sample, which was the time 0 of differentiation. And $\Delta \Delta \mathrm{Cts}$ was calculated based on the efficiency of each primer. GeNorm (Vandesompele et al. 2002) was used to obtain the normalization factor for each sample based on the 2 best endogenous controls that the program selects. Among the 4 internal control genes analyzed ( $G A P D H, S D H A, H M B S$ and HPRT1) GeNorm program selected $G A P D H$ and $S D H A$ to generate the normalization factor used to normalize the samples $\Delta \Delta \mathrm{Cts}$.

\section{DM2 PATIENTS}

We have conducted a case-control study with a total of 345 unrelated patients with DM2. One hundred thirty five patients were ascertained at the Endocrinology Department, Hospital das Clínicas - USP, while the remaining 210 patients are enrolled in a large collaborative study of Diabetes at the University of Rio Grande do Sul, and detailed clinical description can be found elsewhere (Canani et al. 2005, Errera et al. 2007). Briefly, patients with DM2 were identified from a multicentric study that started recruiting patients in southern Brazil in 2002. That project originally aimed to study risk factors for chronic complications of diabetes. It included four centers located at general hospitals in the state of Rio Grande do Sul, namely Grupo Hospitalar Nossa Senhora da Conceição, Hospital São Vicente de Paula, Hospital Universitário de Rio Grande, and Hospital de Clínicas de Porto Alegre. In this study, the ethnical groups were defined based on self-classification and subjective classification (color skin, nose and lip shapes, hair texture and information about family ancestry). All patients are of European ancestry (mainly from Portugal, Spain, Italy and Germany). Patients of African ancestry or those who defined themselves as having mixed or other ancestry were not included. The ethical committees of the participant Institutions approved this study and blood samples were drawn only after signature of the informed consent. Patients underwent a standardized evaluation consisting of a questionnaire, physical examination and laboratory tests. Diagnosis of DM2 was based on the guidelines of the Expert Committee report of the American Diabetes Association (American Diabetes Associa- 
TABLE I

Sequence of the primers used in the Quantitative Real-Time PCR experiment.

\begin{tabular}{c|l|l}
\hline Gene & \multicolumn{1}{|c|}{ Sense Primer $\left(5^{\prime} \rightarrow 3^{\prime}\right)$} & \multicolumn{1}{c}{ Antisense Primer $\left(5^{\prime} \rightarrow 3^{\prime}\right)$} \\
\hline SDHA & TGGGAACAAGAGGGCATCTG & CCACCACTGCATCAAATTCATG \\
\hline HPRT1 & TGACACTGGCAAAACAATGCA & GGTCCTTTTCACCAGCAAGCT \\
\hline HMBS & GGCAATGCGGCTGCAA & GGGTACCCACGCGAATCAC \\
\hline GAPDH & CCATCTTCCAGGAGCGAGAT & TTCTCCATGGTGGTGAAGAC \\
\hline LPL & CTGGCATTGCAGGAAGTCTG & GCATCATCAGGAGAAAGACGA \\
\hline COL18A1 & AAGGACGAGCTGCTGTTTCC & TTGCCGTCAAAGGAGAAGATG \\
\hline
\end{tabular}

tion, 2005). Hypertension was defined as blood pressure $\geq 140 / 90 \mathrm{mmHg}$, or use of antihypertensive medication. Weight without shoes and in light outdoor clothes and height were measured, and body mass index (BMI) was calculated as weight $/$ height $^{2}\left(\mathrm{~kg} / \mathrm{m}^{2}\right)$. Obesity was classified according Word Health Organization (WHO) criteria (World Health Organization 2000). Patients with BMI $\geq 30 \mathrm{~kg} / \mathrm{m}^{2}$ were considered cases and patients with BMI $<30 \mathrm{~kg} / \mathrm{m}^{2}$ as controls.

\section{Peripheral Blood Collection, DNA Extraction AND BIOCHEMICAL Dosages}

Genomic DNA was extracted from peripheral blood leucocytes with salting-out procedure as previously described (Miller et al. 1988). In diabetic patients, glucose was determined by a glucose oxidase method; creatinine by the Jaffé reaction; A1c test by an ion-exchange HPLC procedure (Merck-Hitachi L-9100 Glycated hemoglobin analyzer; reference range: 2.7-4.3\%; Merck, Darmastadt, Germany), and triglyceride and cholesterol levels by enzymatic methods. Albuminuria was measured by immunoturbidimetry (SERA-PAK ${ }^{\circledR}$ immuno Microalbuminuria; Bayer, Tarrytown, NY, mean intra- and interassay CV: $4.5 \%$ and $7.6 \%$, respectively). Total cholesterol, HDL cholesterol and triglycerides were measured by standard enzymatic methods.

ANALysis of SNPS In the COL18A1 Gene Coding REGIONS OF FRIZZLED AND ENDOSTATIN

SNPs c.1136C $>$ T (Thr379Met) and c.4349G $>$ A (Asp1437Asn) were analyzed by SNuPE (Single Nucleotide Primer extension - Amersham Pharmacia) method. Exons 3 (coding region of frizzled domain) and 42 (coding region of endostatin domain) of COL18A1 gene were amplified using PCR buffer, $0.2 \mathrm{mM}$ dNTPs, $0.6 \mu \mathrm{M}$ of each primer; $0.2 \mathrm{U}$ Taq polymerase, in 35 cycles with $100 \mathrm{ng}$ of DNA, according to the following steps: 5 minutes denaturation at $95^{\circ} \mathrm{C}, 10$ minutes extention at $72^{\circ} \mathrm{C}$, and using the following primers and respective annealing temperature: exon $3 F$ : cccaaccacctccaccacgaga and exon $3 R$ : ctggatgaaccgcagccgatgt $\left(66^{\circ} \mathrm{C}\right) ; 42 \mathrm{~F}$ : acaaacacccacacccatc and $42 R$ : gaaactgcagataggaggecc $\left(59^{\circ} \mathrm{C}\right)$. PCR products were submitted to SNuPE reaction and then analyzed in automatic sequencer (MegaBACE ${ }^{\mathrm{TM}} 1000$ DNA Analysis Systems), using the correspondent software and following the User's guide instructions (General Electrics Health Science) and 2 pmols of oligonucleotide [c.1136C $>$ T: CGAGGAAGGGGTGGCAGTGC, and c.4349G>A: GGGCACGCATCTTCTCCTTT (5'-3')].

\section{STATISTICAL ANALYSIS}

Statistical analysis was performed using the SPSS package (SPSS for Windows, version 10.0). Continuous variables were expressed by mean and standard deviation and the groups were compared by unpaired Student $t$ test. Allele frequencies were determined by gene counting, and departures from the Hardy-Weinberg equilibrium (HWE) were verified using the $\chi^{2}$ test. Genotype and allele frequency were compared among different groups by $\chi^{2}$ Test or Fisher's exact test. A $P$ value $<0.05$ was considered statistically significant. Logistic regression analysis was performed to assess the independent role of the COL18A1 genotypes in obesity. Sample size power was calculated with PS Power and Sample Size Calculations (Version 2.1.30) (Dupont and Plummer 1998). 


\section{RESULTS}

COL18A1 GENE EXPRESSION DURING HUMAN ADIPOGENESIS

On day 14 after inducing adipocyte differentiation of adipose tissue-derived human mesenchymal stem cells (hMSCs), we observed that the majority of cells accumulated lipid droplets in the cytoplasm (Fig. 1). In addition, $L P L$, an adipogenic marker, was quantified as a control of the differentiation experiment and it showed extreme high expression levels after the induction of the adipogenesis process (Fig. 2). Therefore, we considered that the stem cell population successfully differentiated into adipocytes.

COL18A1 expression was analyzed at four time points $(0,3,7$ and 14 days) during the differentiation induction and we observed relatively higher expression of this gene at day 3 of the differentiation processes, when it increased 2,5 fold in comparison with undifferentiated cells. At days 7 and 14 the expression was 1.4 and 0.85 fold-higher than that of untreated stem cells (time 0 ), respectively (Fig. 2).

\section{Association Study Between COL18A1 And Obesity}

The main clinical features of the patients are depicted in Table II. Among the 345 patients analyzed, 113 were classified as obese (BMI: $34.31 \pm 4.64$; cases) and 232 as non-obese (BMI: $25.83 \pm 2.53$; controls). Cases also had higher waist and hip circumferences as compared to controls $(P<0.05)$. They also presented higher triglycerides, total and LDL cholesterol $(P<0.05)$. There were no differences for other clinical or laboratorial characteristics. The genotype distribution for SNPs c. $1136 \mathrm{C}>\mathrm{T}$ and c.4349G $>$ A were in HWE (Table III; $P>0.05)$. There was no difference in the genotype or allelic frequencies of the SNP c.4349G $>$ A between obese and non-obese patients $(P=0.11)$. However, a borderline association between SNP c. $1136 \mathrm{C}>\mathrm{T}$ genotypes and obesity was found $(P=0.07)$. Assuming a recessive model (TT vs. $\mathrm{CT}+\mathrm{CC}$ ), the genotype TT was significantly more frequent in obese diabetic patients $(22 / 113,19.5 \%)$ than in non-obese diabetic patients $\left(25 / 232,10.5 \% ; \chi^{2}=4.73\right.$ and $\left.P=0.02\right)$. In this model, patients with TT genotype had an odds ratio (OR) of 2.57 (95\% CI: 1.21-5.47) for obesity. This effect was more pronounced if we exclude individuals with overweight, that is those with BMI between 28 and $30 \mathrm{~kg} / \mathrm{m}^{2}$ [TT genotype frequency in controls (BMI $\left.<27 \mathrm{~kg} / \mathrm{m}^{2}, 12 / 140\right)$ was $8.5 \%\left(\chi^{2}=6.38\right.$ and $P=$ $0.01)]$. In a logistical model, after controlling for cholesterol, triglycerides, LDL cholesterol levels, the TT genotype still held associated with the presence of obesity $(P=0.048$; OR 2,8 CI 95\% 1.01-7.74).

\section{DISCUSSION}

In the present work, we have shown for the first time that human collagen XVIII mRNA levels increase during differentiation of human mesenchymal stem cells (hMSCs) into adipocytes. Its transcription profile observed during the differentiation process suggests that COL18A1 expression increases at an earlier stage of hMSCs adipogenesis, which is comparable to other well known genes associated with adipocyte differentiation, such as $\mathrm{C} / \mathrm{EBP} \beta$ and $\mathrm{C} / \mathrm{EBP} \delta$ (Rosen 2005). These results are in accordance with those observed in the differentiation of bovine preadipocytes obtained from intramuscular fat (Inoue-Murayama et al. 2000). Our results thus indicate that collagen XVIII may play an important role in human adipogenesis and the higher increase of COL18A1 expression in the early phase of adipogenic differentiation point to the importance of this gene in the adipogenic commitment of the cells. It was observed that collagen XVIII expression levels did not vary during adipogenesis of the mouse preadipocyte cell line 3T3-L1 (InoueMurayama et al. 2000). It is therefore possible that the effect of collagen XVIII in adipocyte differentiation depends on the origin of the preadipocyte or it is species related. It is worth to note that we have used primer pairs that recognize the three collagen XVIII isoforms to quantify its expression in human adipocity differentiation, but it would be important to verify if a specific or all collagen XVIII isoforms are involved in this process.

We have also evaluated whether there was an association between COL18A1 gene polymorphisms c. $1136 \mathrm{C}>\mathrm{T}$ and c. $4349 \mathrm{G}>\mathrm{A}$, located respectively in the NC11-728/Frizzled-C18 and NC-1/ES-C18 domains of collagen XVIII, and obesity in type 2 diabetes patients. The allele frequency and genotype distribution for the SNP c.4349G $>$ A in our sample is similar to those previous reported in the literature (Passos-Bueno et al. 2006) and we did not observe any evidence of association 
TABLE II

Clinical variables in DM2 patients according to presence of obesity.

\begin{tabular}{l|c|c|c}
\hline & Controls $(\mathrm{n}=232)$ & Cases $(\mathrm{n}=113)$ & $P$ \\
\hline Gender Female: Male & $122: 110$ & $77: 36$ & \\
\hline DM duration (years) & $12.78 \pm 7.7451$ & $12.81 \pm 7.17$ & 0.97 \\
\hline Age of DM Diagnosis (years) & $48.81 \pm 10.33$ & $44.64 \pm 9.62$ & 0.07 \\
\hline Current age (years) & $60.80 \pm 9.60$ & $60.02 \pm 8.34$ & 0.47 \\
\hline BMI (kg/m2) & $25.83 \pm 2.53$ & $34.31 \pm 4.64$ & - \\
\hline Waist circumference $(\mathrm{cm})$ & $92.88 \pm 9.29$ & $105.36 \pm 12.40$ & 0.00 \\
\hline Hip circumference $(\mathrm{cm})$ & $98.48 \pm 7.54$ & $114.48 \pm 15.33$ & 0.00 \\
\hline Glucose $(\mathrm{mg} / \mathrm{dl})$ & $172.47 \pm 68.43$ & $175.34 \pm 66.73$ & 0.78 \\
\hline LDL- cholesterol $(\mathrm{mg} / \mathrm{dl})$ & $130.27 \pm 46.19$ & $147.70 \pm 48.05$ & 0.01 \\
\hline HDL-cholesterol $(\mathrm{mg} / \mathrm{dl})$ & $45.82 \pm 12.70$ & $44.06 \pm 12.00$ & 0.24 \\
\hline Cholesterol $(\mathrm{mg} / \mathrm{dl})$ & $202.97 \pm 47.14$ & $223.81 \pm 53.41$ & 0.02 \\
\hline Creatinine $(\mathrm{mg} / \mathrm{dl})$ & 1.25 & 1.29 & 0.80 \\
\hline Tryglycerides & $174.08(70-238)$ & $216.98(89-260.8)$ & 0.02 \\
\hline Alc test $(\%)$ & $7.13 \pm 2.36$ & $7.49 \pm 2.53$ & 0.31 \\
\hline Systolic Arterial Pressure $(\mathrm{mmHg})$ & $142.89 \pm 24.02$ & $144.54 \pm 20.85$ & 0.62 \\
\hline Diastolic Arterial Pressure $(\mathrm{mmHg})$ & $85.35 \pm 13.66$ & $87.11 \pm 11.93$ & 0.33 \\
\hline
\end{tabular}

TABLE III

Genotypic and allelic distribution for SNP c.1136C $>$ T and SNP c.4349G $>A$ according to body mass index.

\begin{tabular}{|c|c|c|}
\hline & \multicolumn{2}{|c|}{ Body Mass Index } \\
\hline & $>30 \mathrm{~kg} / \mathrm{m}^{2}(\mathrm{n}=113)$ & $<30 \mathrm{Kg} / \mathrm{m}^{2}(\mathrm{n}=232)$ \\
\hline \multicolumn{3}{|c|}{ SNP c. $1136 \mathrm{C}>\mathrm{T}$} \\
\hline \multicolumn{3}{|l|}{ Genotypes } \\
\hline $\mathrm{CC}-\mathrm{n}(\%)$ & $46(40.7)$ & $111(47.8)$ \\
\hline $\mathrm{CT}-\mathrm{n}(\%)$ & $45(39.8)$ & $96(41.4)$ \\
\hline TT - n (\%) & $22(19.5)$ & $25(10.8)$ \\
\hline \multicolumn{3}{|l|}{ Alleles } \\
\hline $\mathrm{C}$ & $60.6 \%$ & $68.5 \%$ \\
\hline $\mathrm{T}$ & $39.4 \%$ & $31.5 \%$ \\
\hline \multicolumn{3}{|c|}{ SNP c. $4349 \mathrm{G}>\mathrm{A}$} \\
\hline \multicolumn{3}{|l|}{ Genotypes } \\
\hline GG - n (\%) & $102(90.3)$ & $198(85.4 \%)$ \\
\hline GA - n (\%) & $11(9.7)$ & $33(14.2 \%)$ \\
\hline $\mathrm{AA}-\mathrm{n}(\%)$ & $0(0)$ & $1(0.4 \%)$ \\
\hline \multicolumn{3}{|l|}{ Alleles } \\
\hline $\mathrm{G}$ & $95.1 \%$ & $92.5 \%$ \\
\hline $\mathrm{A}$ & $4.9 \%$ & $7.5 \%$ \\
\hline
\end{tabular}




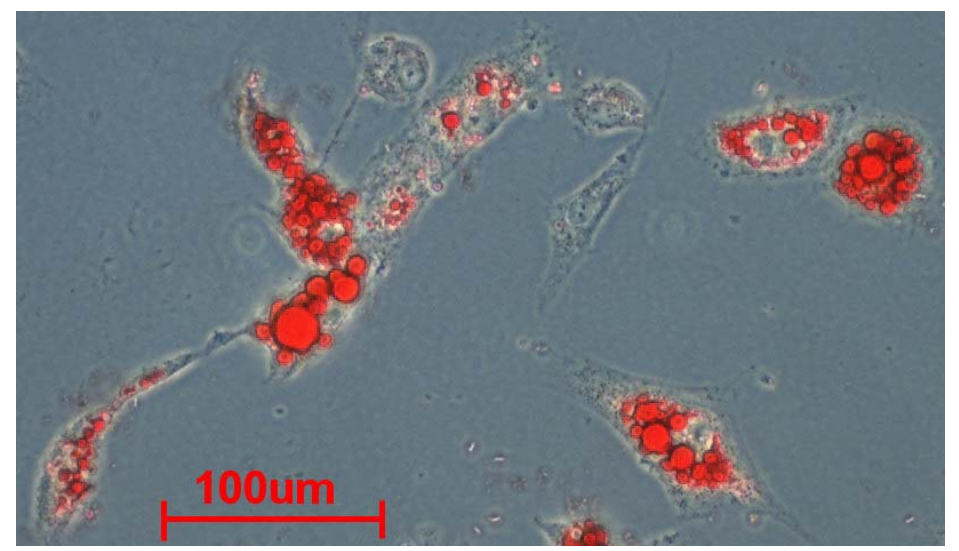

Fig. 1 - Oil red staining of the cells after 14 days of the beginning of adipogenic differentiation showing accumulated lipid vesicles in the cytoplasm.

\section{A}

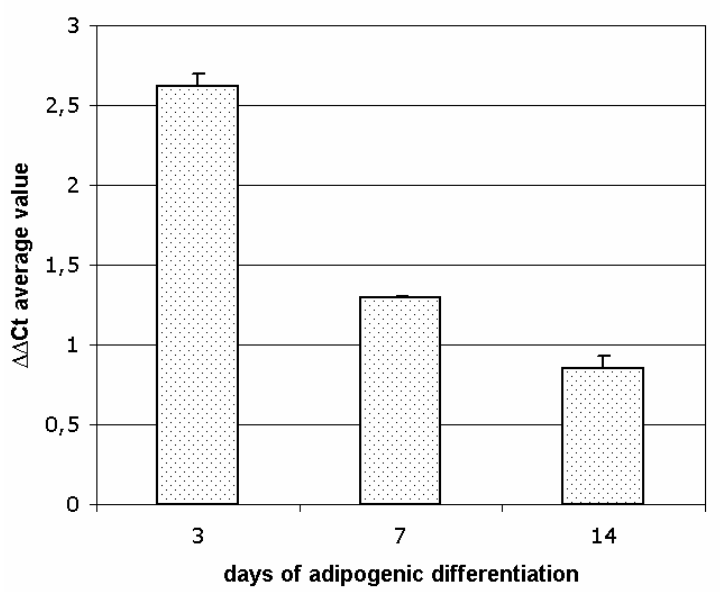

B LPL expression level

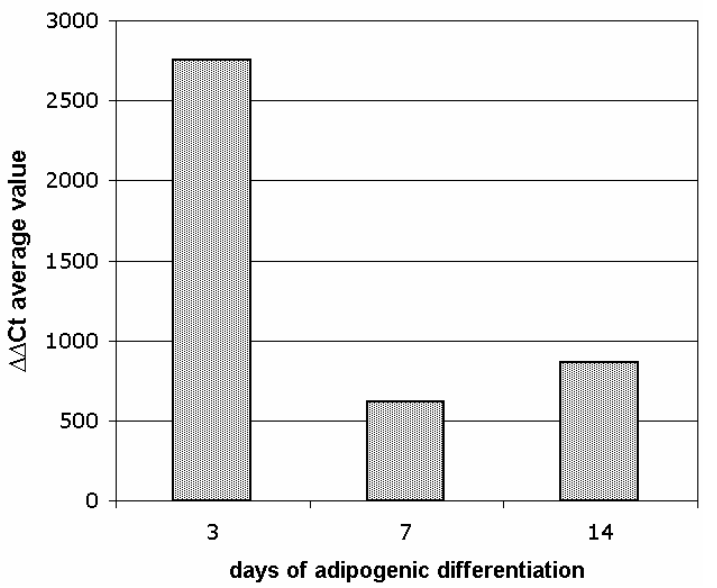

Fig. 2 - A) Quantitative real time PCR showing expression of COL18A1 during human adipogenic differentiation in vitro. B) $L P L$ was quantified as a control of the differentiation experiment and, as expected, it showed high expression levels after the beginning of the adipogenesis process.

between the SNP c.4349G $>$ A and obesity. However, we observed consistent evidence of association between SNP c. $1136 \mathrm{C}>\mathrm{T}$ and obesity.

Our results suggest that the allele c.1136T when in homozygosis increases about two-fold the chance of a DM2 patient to develop obesity. When overweight DM2 patients were excluded from the control group, we found a more pronounced difference in c.1136T frequency between cases and controls, further supporting the association between this SNP and obesity in DM2 patients. The importance of TT genotype for obesity was still confirmed by logistic regression analysis with the following variables: total cholesterol levels, LDL and triglycerides. If these variables are taken into account, the chance that a TT homozygote develops obesity is increased by 2.8 times when compared to CT heterozygotes or CC homozygotes. Hence, our data suggest that TT genotype acts as an independent factor for predisposition to obesity in DM2 patients. The observed frequency of TT genotype in our obese cohort (19.5\%) was very close to the $22 \%$ estimate to achieve an acceptable power level with the sample size available, thus, suggesting that this association might not represent a false positive result. However, although both cases and controls are of EA 
and ascertained in a common cohort of patients, we still cannot exclude the possibility that these results are due to population stratification.

It is well established that proteins with frizzled motif act in Wnt signaling through different pathways in various processes, including adipogenesis, obesity, insulin secretion and DM2 (Ross et al. 2000, Bennett et al. 2002, Kennel and MacDougald 2005, Guo et al. 2006). It has been suggested that the N-terminal portion of collagen XVIII containing the Frizzled-C18 motif could be involved in Wnt signaling (Elaama et al. 2003, Vainio et al. 2003, Marneros and Olsen 2005) and, more recently, Quelard et al. (2006) showed that the Frizzled-C18 module acts as an extracellular inhibitor of Wnt-B-catenin signaling by quenching Wnts in the hepatocarcinoma tumor. The SNP c.1136C $>$ T/Thr379Met is being described in the present work for the first time. In a comparative genomic analysis we verified that threonine at position 379 is conserved among mammals (human, rat, mouse, cow, cat) and is substituted for another polar aminoacid with an uncharged side chain (serine) in other vertebrates (chicken, xenopus, zebrafish, medaka, fugu, stickleback), suggesting that this residue might be important for normal protein function. The frizzled motif of the NC11-728 has a cysteine-rich domain, that contains 10 cysteine-conserved sites, and threonine 379 is located very close to the third cysteine residue. Therefore, it is possible that the presence of a methionine instead of a threonine can partially impair the function of this domain in preadipocyte proliferation or differentiation through a direct or indirect effect of the Wnt pathway.

Recently, we verified that allele c.1136T is in linkage disequilibrium with the $\mathrm{G}$ allele of the polymorphism-700G $>$ T, which confers higher transcription levels to this collagen in hepatocytes (Armelin-Correa et al. 2005). Therefore, we cannot exclude the possibility that the mutated allele is in linkage disequilibrium with another one, which would be actually the responsible for the phenotype.

It has not been reported obesity in patients with null mutations in the collagen XVIII or in the knockout col18-/- mice (Suzuki et al. 2002, Fukai et al. 2002). However, it is possible that the obesity phenotype is induced only in the presence of high food intake or de- pending on the genetic background of the individual. In contrast, obesity is very common in Down syndrome patients, who have three functional copies of COL18A1 gene as the consequence of trissomy of chromosome 21 (Zorick et al. 2001).

COL18A1 and its receptor glypican has been identified as promising candidate genes to be involved with body weight and adiposity in DM2 mice (Brown et al. 2005, Gesta et al. 2006), thus supporting our finding that collagen XVIII is important in adipogenesis and in obesity of DM2 patients.

In conclusion, the present study shows for the first time that collagen XVIII mRNA levels increase during human adipogenesis and that the SNP c.1136C $>\mathrm{T}$ in the frizzled motif of the COL18A1 doubles the chance of a patient with type 2 diabetes to develop obesity. Considering the functional role of collagen XVIII in angiogenesis and that it may be involved in Wnt signaling, we could speculate that this collagen might act in the regulation of adipose tissue mass through different mechanisms: by controlling angiogenesis in fat tissue and by stimulating the differentiation of mesenchymal stem cell into mature adipocytes. Therefore, although preliminary, our present data may be a starting point towards understanding this novel role of collagen XVIII in humans.

\section{ACKNOWLEDGMENTS}

We are grateful to Dr. Carlos Maranduba for helping in patients interviews and molecular analysis, to Dr. Jorge Gross, Dr. Israel Roisenberg, Dr. Daniel Gianella and to Dr. Hugo Lisbôa and his team for kindly providing part of the sample of diabetic patients analyzed in this study, and to Natassia Vieira for helping with the human adipose-derived mesenchymal stem cells characterization, isolation, and differentiation. This research has been supported by Fundação de Auxílio à Pesquisa do Estado de São Paulo/Centro de Excelência em Pesquisa, Inovação e Difusão (FAPESP/CEPID), Conselho Nacional de Desenvolvimento Científico e Tecnológico (CNPq), and Hospital de Clínicas de Porto Alegre. LHC is the recipient of a postdoctoral (ProDoc) grant from Fundação de Coordenação de Aperfeiçoamento de Pessoal de Nível Superior (Fundação CAPES). 


\section{RESUMO}

Colágeno XVIII pode gerar dois fragmentos, um correspondendo à região NC11-728 contendo o motivo "frizzled", o qual possivelmente atua na sinalização Wnt, e outro correspondendo a Endostatina, que é clivada a partir da região $\mathrm{NC1}$ e é uma potente inibidora de angiogênese. Colágeno XVIII e a via de sinalização Wnt foram recentemente associados à diferenciação adipogênica e obesidade em alguns modelos animais, porém ainda não em humanos. No presente trabalho, mostramos que os níveis de expressão gênica do COL18A1 aumentam durante o processo de diferenciação adipogênica em humanos. Também testamos se polimorfismos localizados no motivo "Frizzled" (c.1136C > T; Thr379Met) e na região da Endostatina (c.4349G >A; Asp1437Asn) contribuem na predisposição a obesidade em pacientes com diabetes tipo 2. (113 obesos, BMI $\geq 30$; 232 não-obesos, BMI $<30$ ) de ancestralidade Européia. Nenhuma evidência de associação entre o alelo c.4349G $>$ A e obesidade foi observada, contudo, observamos uma freqüência significativamente maior de homozigotos c.1136TT em obesos (19.5\%) do que em não-obesos (10.9\%) $[\mathrm{P}=0.02 ; \mathrm{OR}=2.0(95 \% \mathrm{CI}: 1.07-3.73)]$, sugerindo que o alelo c.1136T está associado com obesidade conforme um modelo recessivo. Este genótipo manteve-se associado à obesidade $(\mathrm{P}=0.048)$ mesmo após o controle das variáveis colesterol, LDL e triglicérides, e confere um risco 2.8 vezes maior de obesidade. Portanto, nossos dados sugerem o envolvimento do colágeno XVIII em adipogênese humana e predisposição a obesidade.

Palavras-chave: COL18A1, obesidade, adipogênese, endostatina, "frizzled".

\section{REFERENCES}

American Diabetes Association. 2005. Diagnosis and classification of diabetes mellitus. Diabetes Care [WINDOWS-1252?] 28: S37-S42.

ARMELIN-CORREA LM ET AL. 2005. Characterization of human Collagen XVIII promoter 2: interaction of Sp1, Sp3 and YY1 with the regulatory region and a SNP that increases transcription in hepatocytes. Matrix Biol 24: $550-559$.

Balasubramanian SP, Cross SS, Globe J, Cox A, BROWN NJ AND REED MW. 2007. Endostatin gene variation and protein levels in breast cancer susceptibility and severity. BMC Cancer 7: 107-114.

BenNetT CN ET AL. 2002. Regulation of Wnt signaling during adipogenesis. J Biol Chem 277: 30998-31004.

Brown AC, Olver Wi, Donnelly CJ, May ME, NAGGERT JK, ShafFer DJ AND Roopenian DC. 2005. Searching QTL by gene expression: analysis of diabesity. BMC Genet 6: 12-20.

BUENo DF. 2007. Uso de células tronco adultas para estudo da etiopatogenia das fissuras lábio palatinas e bioengenharia de tecidos. Tese de doutorado, Instituto de Biociências, Universidade de São Paulo, SP, Brasil.

CAO Y. 2007. Angiogenesis modulates adipogenesis and obesity. J Clin Invest 117: 2362-2368.

CANANI LH ET AL. 2005. The fatty acid-binding protein-2 A54T polymorphism is associated with renal disease in patient with type 2 diabetes. Diabetes 54: 3326-3330.

Costa AM, Bueno DF, MARTins MT, Kerkis I, Kerkis A, Fanganiello RD, Cerruti H, Alonso N and PASSOS-Bueno MR. 2008. Reconstruction of Large Cranial Defects in Non Immunosuppressed Experimental Design With Human Dental Pulp Stem Cells. J Craniofac Surg 19: 204-210.

Dhanabal M, Ramchandran R, WATERman MJ, LU H, Knebelmann B, Segal M and Sukhatme VP. 1999. Endostatin induces endothelial cell apoptosis. J Biol Chem 274: 11721-11726.

Dupont WD And Plummer JR WD. 1998. Power and sample size calculations for studies involving linear regression. Control Clin Trials 19: 589-601.

Elamaa H, Snellman A, Rehn M, Autio-Harmainen H AND Pihlajaniemi T. 2003. Characterization of the human type XVIII collagen gene and proteolytic processing and tissue location of the variant containing a frizzled motif. Matrix Biol 22: 427-442.

ERRERA FI ET AL. 2007. Functional vascular endothelial growth factor $-634 \mathrm{G}>\mathrm{C}$ SNP is associated with proliferative diabetic retinopathy: a case-control study in a Brazilian population of European ancestry. Diabetes Care 30: $275-279$.

FOLKMAN J. 2002. Role of angiogenesis in tumor growth and metastasis. Semin Oncol 29 (6 Suppl 16): 15-18.

FUKAI N ET AL. 2002. Lack of collagen XVIII/endostatin results in eye abnormalities. EMBO J 21: 1535-1544.

GeSTA S ET AL. 2006. Evidence for a role of developmental genes in the origin of obesity and body fat distribution. Proc Natl Acad Sci USA 103: 6676-6681.

GUO YF ET AL. 2006. Polymorphisms of the low-density lipoprotein receptor-related protein 5 (LRP5) gene are associated with obesity phenotypes in a large family-based association study. J Med Genet 43: 798-803. 
Inoue-Murayama M, Sugimoto Y, Nimmi Y and Aso H. 2000. Type XVIII collagen is newly transcribed during bovine adipogenesis. Differentiation 65: 281-285.

IUGHeTti P ET AL. 2001. A polymorphism in endostatin, an angiogenesis inhibitor, predisposes for the development of prostatic adenocarcinoma. Cancer Res 61: 7375-7378.

John H, RAdTKE K, STANDKER L AND ForsSmanN WG. 2005. Identification and characterization of novel endogenous proteolytic forms of the human angiogenesis inhibitors restin and endostatin. Biochim Biophys Acta 1747: $161-170$.

Kennell JA And MacDougald AO. 2005. Wnt signaling inhibits adipogenesis through beta-catenin-dependent and -independent mechanisms. J Biol Chem 280: 24004 24010.

LOURENÇO GJ ET AL. 2006. High risk of occurrence of sporadic breast cancer in individuals with the $104 \mathrm{NN}$ polymorphism of the COL18A1 gene. Breast Cancer Res Treat 100: 335-338.

Macpherson GR, Singh as, Bennett CL, Venzon DJ, LiEWEHR DJ, FRANKS ME, DAhUt WL, Kantoff PW, PRICE DK AND FigG WD. 2004. Genotyping and Functional Analysis of the D104N Variant of Human Endostatin. Cancer Biol Ther 3: 1298-1303.

Marneros AG And Olsen BR. 2005. Physiological role of collagen XVIII and endostatin. Faseb J 19(7): 716-728.

Miller SA, Dykes DD AND Polesky HF. 1988. A simple salting out procedure for extracting DNA from human nucleated cells. Nucleic Acids Res 16: 1215.

Moulton KS, Olsen BR, Sonn S, Fukai N, ZuraKOWSKI D AND ZENG X. 2004. Loss of collagen XVIII enhances neovascularization and vascular permeability in atherosclerosis. Circulation 110: 1330-1336.

Musso O ET AL. 2001. Tumor hepatocytes and basement membrane-producing cells specifically express two different forms of the endostatin precursor, collagen XVIII, in human liver cancers. Hepatology 33: 868-876.

Nishimura S et AL. 2007. Adipogenesis in Obesity Requires Close Interplay Between Differentiating Adipocytes, Stromal Cells, and Blood Vessels. Diabetes 56: $1517-1526$

Oh SP, Warman ML, Seldin MF, Cheng SD, Knoll JH, TImmons S AND Olsen BR. 1994. Cloning of cDNA and genomic DNA encoding human type XVIII collagen and localization of the alpha-1 (XVIII) collagen gene to mouse chromosome 10 and human chromosome 21. Genomics 19: 494-499.
O’REILLY MS ET AL. 1997. Endostatin: an endogenous inhibitor of angiogenesis and tumor growth. Cell 88: 277285.

Passos-Bueno MR ET AL. 2006. Mutations in Collagen 18A1 (COL18A1) and their relevance to the human phenotype. Anais Acad Bras Cienc 78: 123-132.

QUelard D ET AL. 2006. The frizzled module of col18a1 induces tumor cell death through inhibition of the wntbcatening signaling pathway. Hepatology, AASLD Abstract, $588 \mathrm{~A} \mathrm{p}$.

RoSEN ED. 2005. The transcriptional basis of adipocyte development. Prostaglandins Leukot Essent Fatty Acids 73 : 31-34.

RosS SE ET AL. 2000. Inhibition of adipogenesis by Wnt signaling. Science 289: 950-953.

RUPNICK MA ET AL. 2002. Adipose tissue mass can be regulated through the vasculature. Proc Natl Acad Sci USA 99: 10730-10735.

SaARela J, Ylikarppa R, Rehn M, PURMONEN S AND Pihlajaniemi T. 1998. Complete primary structure of two variant forms of human type XVIII collagen and tissue-specific differences in the expression of the corresponding transcripts. Matrix Biol 16: 319-328.

SAsaki T, Fukai N, Mann K, Gohring W, Olsen BR AND TIMPL R. 1998. Structure, function and tissue forms of the C-terminal globular domain of collagen XVIII containing the angiogenesis inhibitor endostatin. EMBO J 17: 4249-4256.

Schmidt A, Wenzel D, Ferring I, KAZEmi S, SAsaki T, Hescheler J, Timpl R, Addicks K, FleischMANN BK AND BLOCH W. 2004. Influence of endostatin on embryonic vasculo- and angiogenesis. Dev Dyn 230: 468-480.

Sertié AL, Sossi V, Camargo AaA, Zatz M, Brahe C AND PAssos-Bueno MR. 2000. Collagen XVIII, containing an endogenous inhibitor of angiogenesis and tumor growth, plays a critical role in the maintenance of retinal structure and in neural tube closure (Knobloch syndrome). Hum Mol Genet 9: 2051-2058.

SUZUKI OT ET AL. 2002. Molecular analysis of collagen XVIII reveals novel mutations, presence of a third isoform and possible genetic heterogeneity in Knobloch syndrome. Am J Hum Genet 71: 1320-1329.

Udagawa T, Fernandez A, Achilles E, Folkman J AND Amato RJ. 2002. Persistance of microscopic human cancers in mice: alterations in the angiogenic balance accompanies loss of tumor dormancy. Faseb J 16: 13611370 . 
VAinio S, Lin Y AND Pinlajaniemi T. 2003. Induced Repatterning of Type XVIII Collagen Associates with Ectopic Sonic Hedgehog and Lung Surfactant C Gene Expression and Changes in Epithelial Epigenesis in the Ureteric Bud. J Am Soc Nephrol 14 (Suppl 1): S3-8.

Vandesompele J, De Preter K, Pattyn F, Poppe B, Van Roy N, De Paepe A and Speleman F. 2002. Accurate normalization of real-time quantitative RT-PCR data by geometric averaging of multiple internal control genes. Genome Biol 3(7): RESEARCH0034.

WHO. 2000. Obesity: preventing and managing the global epidemic. In: REPORT ON A WHO CONSULTATION. Geneva, World Health Organization, Technical Report Series 894.
WodArz A AND NusSe R. 1998. Mechanisms of Wnt signaling in development. Annu Rev Cell Dev Biol 14: 59-88.

ZORICK TS ET AL. 2001. High serum endostatin levels in Down syndrome: implications for improved treatment and prevention of solid tumours. Eur J Hum Genet 9: 811-814.

ZUK PA ET AL. 2002. Human adipose tissue is a source of multipotent stem cells. Mol Biol Cell 13: 4279-4795. 